\title{
Re-Os and Sm-Nd Isotope Systematics of Alkaline Ultramafic Rocks, Xenoliths and Macrocrysts from the Earaheedy Basin, Yilgarn Craton
}

\author{
Graham, S. ', Lambert, D.D.', Shee, S.R. ${ }^{2}$, Smith, C.B. ${ }^{3}$ and Hamilton, R. ${ }^{4}$ \\ 1 Victorian Institute of Earth and Planetary Sciences, Department of Earth Sciences Monash University, Clayton, \\ 3168, Australia \\ 2 Stockdale Prospecting Pty. Ltd, South Yarra, 3141, Australia \\ 3 Rio Tinto Exploration Pty. Ltd, Bundoora, 3083, Australia \\ 479 Todd Ave, Como, 6152, Australia
}

\section{Introduction}

In order to understand better the role of the continental lithospheric mantle and incompatible element enrichment processes in the generation of alkaline ultramafic rocks we have obtained Carius tube/N-TIMS Re-Os isotopic data from kimberlites, melnoites, oxide macrocrysts and lherzolite xenoliths from the Earaheedy Basin, Western Australia. We have previously demonstrated that marginal, on-craton Yilgarn melnoites and picroilmenite macrocrysts have a source prehistory coincident with metasomatism-accretion of fertile lithospheric mantle during Proterozoic orogenesis (Graham et al., 1996). Re-Os isotopic data from ilmenite megacrysts and pyroxenite xenoliths from South African kimberlites (Olive et al., 1997) support our previous conclusions that younger lithospheric mantle can be accreted to the continental lithospheric mantle by upper mantle incompatible element enriched melts.

\section{Background Geology}

The northern margin of the Eastern Goldfields Province is defined by rock sequences of the Earaheedy Basin (Fig. 1). The basin is one of the structural features which belong to the $2200-$ 1600 Ma Capricorn Orogen. Basin basement rocks are probably Archaean Yilgarn granitoidgreenstones and the internal structure of the Capricorn Orogen is interpreted to reflect PilbaraYilgarn collision which resulted in basin development (Tyler et al. in press). Three alkaline ultramafic provinces of different ages occur within and near the Earaheedy Basin. Emplacement ages range from 1900 - $1700 \mathrm{Ma}$ (Nabberu kimberlites: Shee et al., 1996), $1329 \pm 9$ Ma (Jewill kimberlites: unpubl. Rio Tinto K-Ar phlogopite data), to $305 \mathrm{Ma}$ (Bulljah melnoites: Hamilton and Rock, 1990, SHRIMP zircon).

\section{Geochemical and Isotopic Results}

Whole rock kimberlite and melnoite samples are enriched in LILE, HFSE and LREE, consistent with literature data for alkaline ultramafic rocks. The Nabberu kimberlite has a flat primitive mantle normalised PGE pattern, similar to continental lithospheric mantle peridotites, kimberlites and orangites (Fig. 2). The Bulljah melnoite has a fractionated PGE pattern, similar to patterns observed in mantle melts. The negative Pd anomaly, a feature observed in all melnoites from the Yilgarn Craton, may result from fractionation of spinel or be a characteristic of Yilgarn melnoite sources. Re/Os concentration ratios for kimberlites are variable and range from 0.035 to 0.138 , while $\mathrm{Re} / \mathrm{Os}$ ratios for the melnoites are significantly higher $(0.107$ to 1.261$)$ indicating a higher degree of partial melting or smaller percentage of xenocrysts than the kimberlites (Fig. 3 ).

Sm-Nd isotopic data from the Nabberu kimberlites and Bulljah melnoite provide evidence for two distinct sources. The Nabberu kimberlites have an unradiogenic initial $\varepsilon_{\mathrm{Nd}}$ isotopic composition $\left(\varepsilon_{\mathrm{Nd}}=-7\right)$. The Bulljah melnoite also has an unradiogenic initial isotopic composition $\left(\varepsilon_{\mathrm{Nd}}=-20\right)$, but is radiogenic at $1900 \mathrm{Ma}$. Sm-Nd $\mathrm{T}_{\mathrm{DM}}$ model ages for the two rock types also show distinct differences, the Nabberu kimberlites have model ages of $\sim 2700 \mathrm{Ma}$ while the melnoite has model age of $2100 \mathrm{Ma}$. Sm-Nd isotopic and PGE data argue strongly against a genetic link between the two rock types, despite their incompatible trace element affinities and close spatial association. Although the $\sim 2700 \mathrm{~T}_{\mathrm{DM}}$ model ages from the Nabberu kimberlite are similar to Marymia Dome crustal ages contamination is discounted as alkaline ultramafic rocks have $\mathrm{Sm}$ and $\mathrm{Nd}$ concentrations greater than average crust. The data may therefore be representative of anomalous enriched regions of continental lithospheric mantle beneath this region.

Re-Os isotopic data for the three provinces reveal an interesting and significant evolutionary history for the source regions of these alkaline ultramafic rocks. Whole rock data for kimberlite and their mantle xenoliths are isochronous (Fig. 4). The chondritic initial ${ }^{187} \mathrm{Os} /{ }^{188} \mathrm{Os}$ isotopic 
ratio of 0.1159 and the $2061 \pm 248 \mathrm{Ma}$ age are consistent with the active margin phase of Pilbara and Yilgarn Craton accretion (Tyler and Thorne, 1990). We interpret this line to represent a "mantle isochron", because the isotopic composition of kimberlites can be dominated by disaggregated lithospheric mantle (Pearson et. al., 1995). Thus, this isochron reveals the age of the shallow mantle beneath the Earaheedy Basin.

Re-Os isotopic data for whole rocks and spinels from the Bulljah melnoite yield an isochron with an age of $1281 \pm 115 \mathrm{Ma}$, MSWD $=13$ (Fig. 5). We interpret this age as the age of emplacement because the $305 \mathrm{Ma}$ emplacement age was determined from 3 zircons which have U contents far greater $(\mathrm{U}>100 \mathrm{ppm})$ than those typical alkaline ultramafic rocks, also the Re-Os age is within error of the K-Ar phlogopite emplacement age of the Jewill kimberlite. The sub-chondritic initial ${ }^{187} \mathrm{Os} /{ }^{188} \mathrm{Os}$ for the isochron is inconsistent with the near chondritic and radiogenic Os isotopic ratios observed in asthenospheric and plume mantle melts respectively. The low isochron initial is however consistent with the melnoites being the melt of continental lithospheric mantle that had possessed a lower Re/Os ratio than the asthenospheric mantle for a long period of time. The low isochron initial ${ }^{187} \mathrm{Os} /{ }^{188} \mathrm{Os}$ will allows a $\mathrm{T}_{\mathrm{RD}}$ model age to be calculated. This model age will have a geological meaning only if it approximates the lithospheric mantle source of the melnoite and if the source was devoid of Re at $1281 \mathrm{Ma}$ The initial ${ }^{187} \mathrm{Os} /{ }^{188} \mathrm{Os}$ isotopic composition has a calculated Re-Os $T_{R D}$ minimum $\mathrm{Re}$ depletion model age of $\sim 2200 \mathrm{Ma}$, within error of the kimberlite isochron (Fig. 6). The melnoite isochron therefore places important constraints on the nature of mantle sources for alkaline ultramafic rocks from the Earaheedy Basin.

The lack of diamond from the Bulljah melnoite is consistent with a larger melt component in these rocks compared to diamondiferous kimberlites of the same age located further west. The $\mathrm{Re}$-Os data. in contrast to the Sm-Nd and PGE data, confirm a genetic link between kimberlites and melnoites. Moreover, the data show that it is highly likely that both rock types are derived from the lithospheric mantle and that source melting must be achieved through processes other than simple plume-continental lithospheric mantle interaction.

\section{Conclusions}

$\mathrm{Re}-\mathrm{Os}$ and $\mathrm{Sm}-\mathrm{Nd}$ isotopic data for alkaline ultramafic rocks from the Earaheedy Basin are consistent with accretion of new lithospheric mantle during orogenesis ( 2200 - $2000 \mathrm{Ma})$. Furthermore, emplacement ages coincide with upper crustal basin extension (Nabberu $1700 \mathrm{Ma}$; Bangemall 1400 - $1300 \mathrm{Ma}$ ). Archaean lithospheric mantle of the proto-Earaheedy Basin may have been extensively thinned and replaced by accreted melt depleted oceanic lithospheric mantle at $\sim 2100 \mathrm{Ma}$. Incompatible element enrichment of the sources also occurred at this time. Re-Os isotopic data from the Bulljah melnoite suggest a genetic relationship between the kimberlites and melnoite. No diamonds are found in association with the melnoite because of the larger degree of partial melting.

\section{References}

Graham, S., Lambert, D.D., Shee, S.R., Hamilton, R., and Foster, J.G., 1996, Source regions for Norseman and Lara melnoites, Western Australia: Trace element and Rb-Sr, Sm-Nd and Re-Os isotopic constraints: Geol. Soc. Aust. Abstracts 41, p. 162.

Hamilton, R., and Rock, N.M.S., 1990, Geochemistry, mineralogy and petrology of a new find of ultramafic lamprophyres from Bulljah Pool, Nabberu Basin, Yilgarn Craton, Western Australia: Lithos 24., p. 275-290.

Olive, V., Ellam, R.B., and Harte, B., 1997, A Re-Os isotope study of ultramafic xenoliths from the Matsoku kimberlite: Earth Planet. Sci. Lett., 150, p. 129-140.

Pearson, D.G., Rogers, N.W., Irving, A.J., Smith, C.B., and Hawkesworth, C.J., 1995, Source regions of kimberlites and lamproites: Constraints from Re-Os isotopes: Extended abstracts, 6 th I.K.C., p. 430-432.

Shee, S.R., Vercoe, S.C., Wyatt, B.A., Campbell, A.N., Coglan, E.A., Hwang, P.H., and Merritt, B.D., 1996, The Nabberu Kimberlite Province, Western Australia: Exploration, petrology and structural setting: Geol. Soc. Aust. Abstracts., 41, p. 387.

Tyler, I.M., Pirajno, F., Bagas, L., and Myers, J.S., (in press), Geology and mineral deposits of the Proterozoic in Western Australia. AGSO Journal of Geology and Geophysics, 17. 


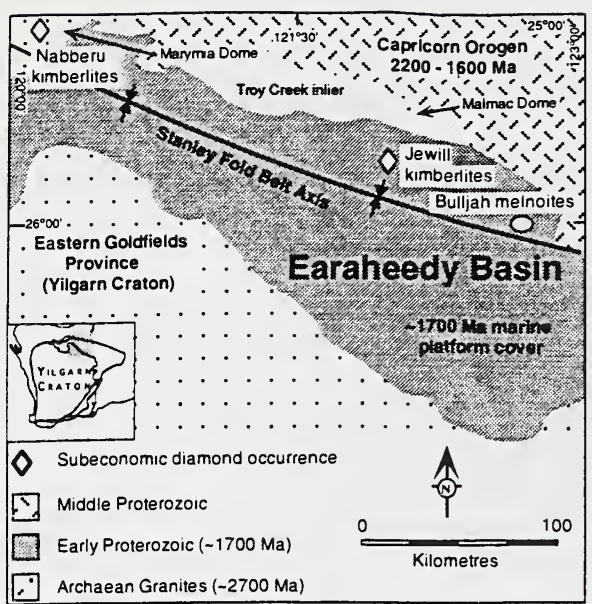

Figure 1. Earaheedy Basin Geology

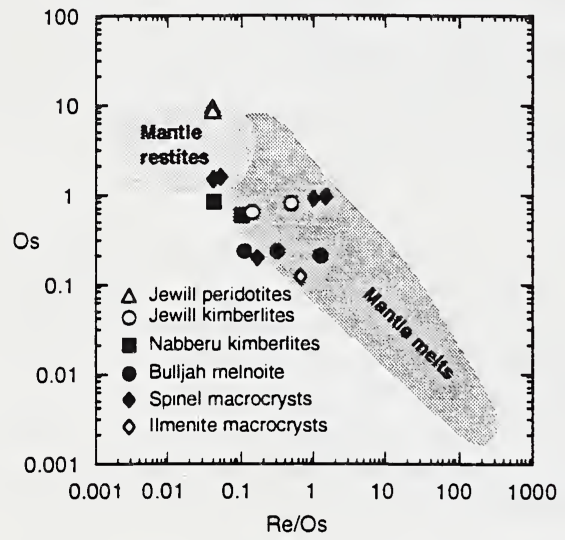

Figure $3 \mathrm{Re}-\mathrm{Os}$ mantle array

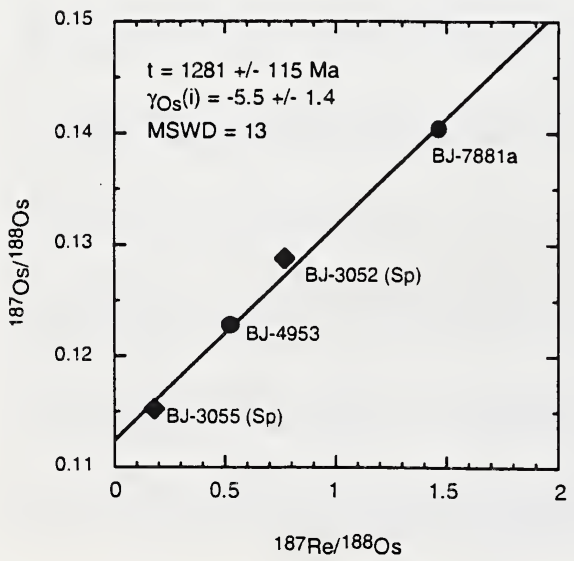

Figure 5. Melnoite isochron

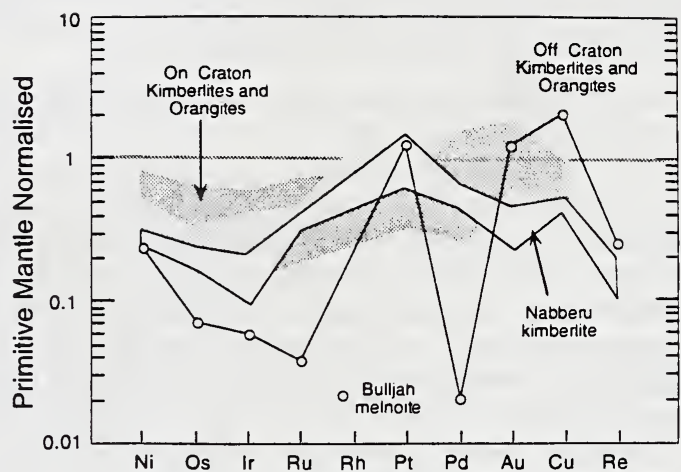

Figure 2. PGE abundances

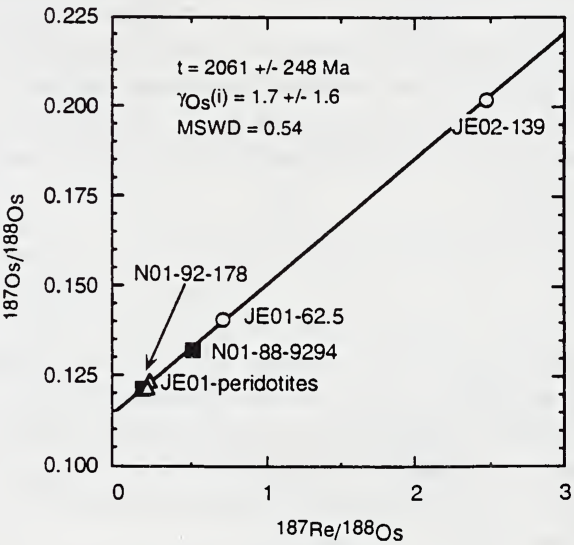

Figure 4. Kimberlite isochron

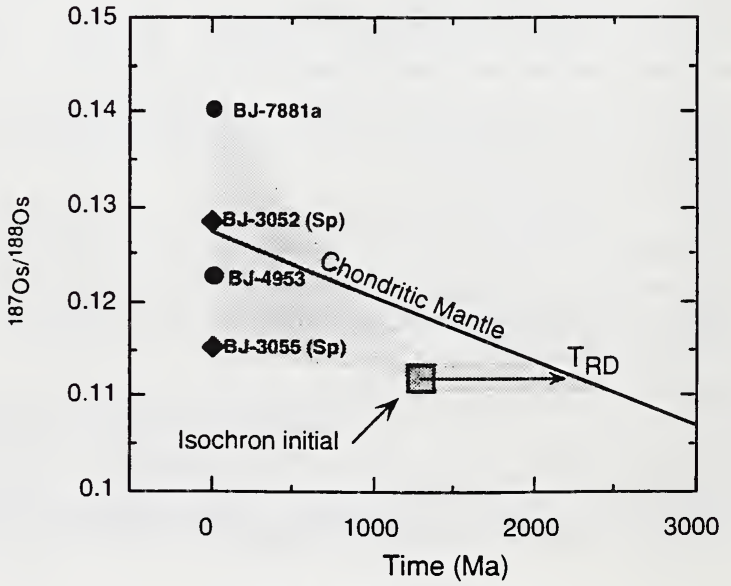

Figure 6. Bulljah Os evolution 